\title{
Bolşevik İhtilali'nin İran'daki Yansımaları
}

Kamuran Karabalık

(ORCID: 0000-0003-4703-8412)

Makale Gönderim Tarihi

26.04.2021
Makale Kabul Tarihi

19.09.2021

\section{Atıf Bilgisi/Reference Information}

Chicago: Karabalık, K., “Bolşevik ihtilali'nin İran'daki Yansımaları”, VakanüvisUluslararası Tarih Araştırmaları Dergisi, 6/2 (2021): 661-688.

APA: Karabalık, K. (2021). Bolşevik intilali'nin İran'daki Yansımaları. VakanüvisUluslararası Tarih Araştırmaları Dergisi, 6 (2) , 661- 688.

\section{Öz}

Birinci Dünya Savaşı'nın sebep olduğu iktisadi yük, 1917 'de Rusya'da iç karışı|ılıların artmasına sebep oldu. Başlangıçta halk hareketleri olarak başlayan olaylar, Bolşeviklerle Menşeviklerin birlikte hareket etmesiyle büyük bir ihtilale dönüştü. İhtilalin yankıları XIX. yüzyıldan beri Rus baskısı altında olan İran'da sevinçle karşılansa da yeni kurulan Geçici Hükümetin savaş taraftarı olmasıyla bu sevinç kısa sürdü.

Geçici Hükümet'in aksine savaş karşıtı olan Bolşevikler, Ekim 1917'de yeni bir darbeyle iktidarı ele geçirdiler. Bolşeviklerin amacı, "ilhak veya tazminatların" olmadığı, "demokratik" bir barışı sağlamak için savaşı sona erdirmekti. Bolşeviklerin talebi üzerine Itttifak devletleri ile Rusya arasında 22 Aralık 1917 'de barış görüşmeleri başladı. Görüşmeler sırasındaki önemli meselelerden biri de İran'dı. Ruslar, bu görüşmeler sırasında XIX. yüzyıldan beri İran üzerinde kurdukları siyasi, askeri ve ticari ayrıcalıklarından vazgeçeceklerini ve askerlerini İran'dan çekeceklerini açıkladılar. Taraflar arasındaki görüşmeler 3 Mart 1918 imzalanan Brest-Litovsk Antlaşması ile son buldu. Bu antlaşma ile Rusya'nın İran üzerindeki tahakkümü sona ererken, Rusya ve Osmanlı Devleti

\footnotetext{
* Arş. Gör., Bülent Ecevit Üniversitesi Fen-Edebiyat Fakültesi Tarih Bölümü, Türkiye, kamurankbalik@gmail.com.

Research Assistant, Bülent Ecevit University Faculty of Arts and Sciences Department of History, Turkey.
}

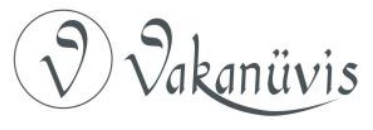


ordularını İran'dan geri çekeceklerdi. Fakat Rus askerlerinin çekilmesi üzerine İran'da ortaya çıkan otorite boşluğunu doldurmak isteyen İngilizler, Ermeniler ve Nasturiler hareket geçtiler. Bu durum bölgedeki karmaşayı daha da arttırdı.

Bu çalışmanın amacı, XIX. yüzyıldan beri başlayan ve Birinci Dünya Savaşı sırasında daha da artan İran üzerindeki Rus tahakkümünün Bolşevik Ihtilali ile nasıl sona erdiğini kaynaklar ışığında incelemektir.

Anahtar Kelimeler: Ruslar, İran, Birinci Dünya Savaşı, Bolşevik ihtilali, BrestLitowsk Antlaşması

\section{Reflections of the Bolshevik Revolution on Iran}

\section{Abstract}

The economic burden arising from the First World War brought about a surge in internal disturbances in Russia in 1917. Starting as grassroots movements, the incidents transformed into a great revolution with the cooperation of the Bolsheviks and Mensheviks. Even though the repercussions of the revolution were welcomed by Iran, which had been under Russian dominance since the 19th century, the enthusiasm did not last long with the bellicist stance of the newly-established Provisional Government.

Being anti-war, unlike the Provisional Government, the Bolsheviks staged a coup in October 1917 to seize power. The purpose of the Bolsheviks was to end the war in order to establish a "democratic" peace without "annexations or reparations". Upon the request of the Bolsheviks, the peace negotiations between the Central Powers and Russia were initiated on 22 December 1917. One of the significant matters discussed during these negotiations was Iran. The Russians stated during these negotiations that they would relinquish the political, military and commercial privileges they had established on Iran since the 19th century. The negotiations between the parties were concluded with the Treaty of Brest-Litovsk signed on 3 March 1918. The treaty ended Russian dominance over Iran while requiring Russia and the Ottoman Empire to withdraw their troops from Iran. However, desirous of filling the power gap in Iran resulting from the withdrawal of Russian troops; the British, the Armenians and the Nestorians took action. This complicated the turmoil in the region even further.

The purpose of the present study is to examine how the Russian dominance on Iran, starting from the 19th century and becoming even stronger during the First World War, ended with the Bolshevik Revolution based on historical sources.

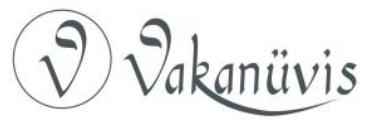


Keywords: Russians, Iran, First World War, Bolshevik Revolution, Treaty of Brest-Litovsk

\section{Giriş}

Rusların, İran coğrafyasındaki faaliyetleri XIX. yüzyılda başladı. İran'ın Gürcistan üzerinde hâkimiyet kurmaya çalışması, iki devleti karşı karşıya getirdi ${ }^{1}$. Bu durum İran ile Rusya arasında bir dizi savaşa (1804-1812 ve 1826 savaşları) sebep oldu. İki devlet arasında başlayan bu savaşlar sonucunda imzalanan Gülistan (1813) ve Türkmençay (1828) antlaşmalarıyla ${ }^{2}$ İran, topraklarının önemli bir kısmını Rusya'ya kaptırdı. Bu durum Rusya'nın hem Kafkasya'nın güneyine inmesini kolaylaştırdı hem de İran üzerinde siyasi, askeri ve ticari faaliyetlerinin artmasının önünü açtı ${ }^{3}$. Rusya'nın İran'daki bu faaliyetleri, XIX. yüzyılın ortalarından itibaren arttı. Bu durum İngiltere'yi tedirgin ediyordu. Çünkü İran, Ingiltere'nin Hindistan sömürgesine giden yolu üzerindeydi. Dolayısıyla Rusya'nın bölgedeki faaliyetlerine set çekmek isteyen İngiltere, İran ile

\footnotetext{
${ }^{1}$ Lokman Dehkan Neyyiri, "Yüzyılın İlk Yarısında İran ve Osmanlı Devletlerinin Zayıflatılması ve Avrupa'nın Bundaki Rolü". Onuncu ve Yirminci Yüzyıllar Arasında Iranlılar ve Türklerin Batıyla ilişskileri, Çev., Sayyid Abu Talib Ruhani, Ziya Türkyılmaz, Omid Rambod, Uluslararası Kültürel İncelmeler Merkezi, Tahran 2005, s. 61.

2 Rusya ile İran arasında 1804'de başlayan savaşlarda Rusya, Azerbaycan coğrafyasının büyük bir bölümünü işgal etmişti. Bu savaş sonucunda imzalanan Gülistan Antlaşmasına göre; Talış, Şirvan, Kuba, Bakü, Derbent, Gence, Karabağ ve Şeki Hanlıkları Rusya'nın hâkimiyetine bırakıldı. İran'ın Rusya'ya kaptırdığı topraklarını geri almak istemesi üzerine iki devlet arasında tekrar mücadele başlamış ve Rusya tekrar başarılı olmuştu. Bunun üzerine iki devlet arasında Türkmençay Antlaşması imzalanmıştı. Antlaşmaya göre; bu antlaşma ebedi barış, dostluk ve işbirliği antlaşması olarak kabul edilecekti. İran, 6 ay içerisinde Revan ve Nahçıvan Hanlıklarını Rusya'ya bırakacak, iki devlet arasındaki sınır tespit edilecek ve tespit edilen sınırların kuzeyinde kalan, Kafkas sıra dağları ve Hazar Denizi arasında bulunan bütün toprak ve adaların, bu topraklarda yaşayan halkların Rusya İmparatorluğu'na ait olduğu kabul edildi. Ayrıca Hazar Denizi'nde her iki devletin de ticaret gemileri yüzebilecek, fakat yalnızca Rusya'nın savaş gemileri bulunabilecekti. Ayrıntılı bilgi için bknz: Okan Yeşilot, "Türkmençay Antlaşması ve Sonuçları", A.Ü. Türkiyat Araştırmaları Enstitüsü Dergisi, S. 36, (2008), s. 189-190.

${ }^{3}$ Cafer Mehdi Niya, Heft Bar İşgal-i Iran der 23 Karn. C. 4, İntişarat-ı Panos, Tahran 1377. s. 81.
}

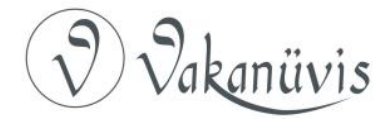


ilişkilerini artırdı ${ }^{4}$. Bu durum 1870'lerden itibaren İran'daki Rus-İngiliz rekabetini hızlandırdı 5 .

İran üzerindeki İngiliz-Rus rekabeti, XX. yüzyılın başarında da devam etti. Ingiltere ve Rusya arasında müzakere edilip imzalanan "1907 ingiliz-Rus Antlaşması" ${ }^{\prime 6}$ ile İran üç nüfuz bölgesine ayrıldı. Buna göre İran'ın orta kısmı tarafsız olmakla birlikte İran'ın kuzeyi Rusya'nın, güneyi ise İngiltere'nin kontrolü altına girdi. Ruslar, İran'ın kuzeyine yerleştikten sonra hem bölgede hem de burada meskûn olan Ermeniler, Nasturiler ve bazı Kürt aşiretleri (Simko İsmail Ağa, Abdurrezak v.b) arasındaki faaliyetlerini artırdılar. Rusların, bu halkları örgütleyerek Osmanlı-İran sınırında asayiş sorunlarına sebep olmaları üzerine Osmanlı Devleti ile Rusya karşı karşıya geldi ${ }^{7}$.

Birinci Dünya Savaşı başladıktan sonra da Rusya'nın İran'daki bu faaliyetleri devam etti. Rus askerleri 1911'den beri bölgede olduklarından savaş başlar başlamaz bulundukları bölgeleri resmen işgal ettiler. Rusya'nın bölgeye yönelik amaçlarının başında, bölgeyi işgal ederek Basra Körfezi'ne inmek ve ayrıca İran'ın kuzeyindeki petrolleri denetim altına almaktı ${ }^{8}$. Bu sebeplerden dolayı Ruslar, kendi askeri planlarının bir parçası olarak, bölgedeki farklı etnik ve dini gruplar

${ }^{4}$ Yılmaz Karadeniz, Iran'da Sömürgecilik Mücadelesi ve Kaçar Hanedanı (1795-1925). Bakış Yayınları, İstanbul, 2006, s. 219.

${ }^{5}$ Charles Issawi, "Iranian Trade, 1800-1914". Iranian Studies, C. 16, (1983), s. 234-235. 6ingiltere ve Rusya arasında İran Devleti'ni hiçe sayarak imzaladıkları bu antlaşmaya göre; İran'ın kuzeyi Rusya'nın, güneyi de İngiltere'nin kontrolünde olacaktı. Bunun dışında kalan bölgede de tarafsız bölge ilan edilerek İran'ın kontrolüne bırakıldı. Ayrıca iki devlet yalnızca kendilerine ayrılan bölgede imtiyaz aramayı; Belçikalı gümrük memurlarını yerlerinde bırakmayı, önceki borçların geri ödemeleri için gümrük gelirlerini kullanmayı kararlaştırdılar. İngiliz ve Rus kredilerinin ödenmesi için de İran'ın gümrük gelirleri üzerinde ortak denetim kararı alındı. Bu antlaşma iki devletin İran üzerindeki otoritelerini güçlendirdi. Chris Paine and Erica Schoenberger, "Iranian Nationalism and the Great Powers: 1872-1954". MERIP Reports, S. 37, (1975), s. 4; Bijan Cezani, Iran Meşrutiyet Devrimi (1906-1911), Kaynak Yayınları, İstanbul 2004, s. 224227.

7 Fatih Ünal, "Şikak Aşireti ve Reisi Simko Lakaplı İsmail Ağa'nın Faaliyetleri", Tarih Dergisi, C. 0/44, (2006), s. 77.

8 Kamuran Karabalık, Birinci Dünya Savaşı'nda Güney Azerbaycan, Bolu Abant İzzet Baysal Üniversitesi, Sosyal Bilimler Enstitüsü Yayımlanmamış Doktora Tezi, Bolu 2019, s. 3.

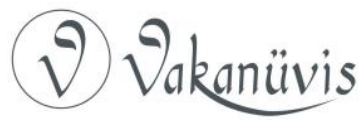


arasındaki husumetleri kışkırtmayı veya daha da kızıştırmayı amaçlayan politikalar izlediler.

Rusların hem İran'daki Müslüman halka baskı uygulamaları hem de Osmanlı-İran sınırında asayiş problemlerine sebep olmaları Osmanlı birliklerinin İran topraklarına girmesine sebep oldu. Osmanlı birliklerinin İran topraklarına girmesi bölgeyi savaş alanı haline getirdi. Bu sırada Ermeniler, Nasturiler ve bazı Kürt aşiretleri de Rusları destekleyerek Osmanlı Devleti'ne karşı savaştılar. İran hükümeti ise 1 Kasım 1914'de tarafsızı̆̆ını ilan etmesine rağmen siyasi ve askeri bir güçten yoksun olduğundan ülkedeki olaylara müdahale edemedi. İran topraklarındaki Osmanlı-Rus savaşı, 1917 yılına kadar devam etti. 1917 yılında Rusya'da patlak veren ìntilal, İran'daki faaliyetlerinin sona ermesine sebep oldu. Aynı yıl Ruslar, İran'da farklı planlar yapmaktaydılar. Rusların planı, 1917'nin başlarında Irak'ta Osmanlı Devleti'nin karşısında zor durumda kalan İngilizlere yardım ulaştırmaktı. Fakat intilal 'den dolayı Rusların bu planı suya düştü. Rusya'da iktidara gelen ve savaş karşıtı bir politika izleyen Bolşevikler, askerlerini İran'dan çekmeyi ve İran'daki bütün ayrıcalıklarından vazgeçmeyi kabul ettiler.

\section{Rusya'da îhtilalin Başlaması ve İran'daki İlk Yansımaları}

Ruslar, Birinci Dünya Savaşı sırasında savaşmakta oldukları İran'da yeni planlar yaparken 1917 'de ülkede ortaya çıkan bazı gelişmeler bu planın uygulanmasını olanaksız hale getirdi. Rus ekonomisinin bozulması, bu gelişmelerin önemli sebeplerinden biriydi ${ }^{9}$. Rus ekonomisinin bozulmasının en önemli sebeplerinden biri savaştı. Çünkü savaş, ülke için ek maliyet çıkarmaya başlamıştı. Seferberliğe alınan yaklaşık 18 milyon insanın ihtiyacını karşılamak Rusya'yı zor durumda bırakmaktaydı. Haliyle savaş maliyetlerini karşılayamayan ülkenin borcu arttı. Nitekim savaş başladığında ülkenin borcu 9,5 milyon ruble iken, 1917 'ye gelindiğinde borç 40,8 milyon rubleye yükselmişti ${ }^{10}$. Rusya'nın içine düştüğü bu zafiyet ülkedeki sosyalist örgütleri aktif hale getirdi. Bu örgütler, savaş tüm sıcaklığı ile devam ederken 27 Şubat (12 Mart)

\footnotetext{
91917 yılının ilk aylarında Rusya'da meydana gelen gelişmelerin ayrıntılı sebepleri için bknz: E. H. Car, Sovyet Rusya Tarihi, Bolşevik Devrimi (1917-1923), çev., Tuncay Birkan, Metis Yayınları, İstanbul 2004.

10 Ramin Sadıgov, "Bolşeviklerin Geçici Hükümeti Devirme Girişimi: 1917 Temmuz Ayaklanması”, Tarih Incelemeleri Dergisi, C. XXXIV / 1, (2019), s. 231.
}

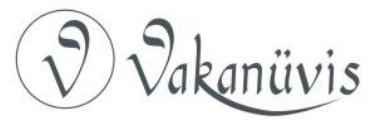


1917 'de Petrograd'da mevcut yönetim aleyhine gösteriler düzenlediler. Bu gösterilere halk kitleleriyle beraber askeri birliklerin de destek vermesiyle hükümet kuvvetleri ile göstericiler arasında çatışmalara sebep oldu. Hükümet kuvvetlerinin göstericiler karşısında başarısız olması üzerine ihtilalde önemli bir rol üstelenen "İşçi ve Askerin Sovyeti" teşkilatı kuruldu. Bundan sonra, Sovyet yetkilileri ile Duma temsilcileri arasında müzakereler başladı ${ }^{11}$. Müzakereler sırasında Çar'ın tahttan feragat etmesi ve geçici bir hükümetin kurulması kararlaştırıldı. Böylece Çarlık rejimi sona erdi ${ }^{12}$. 14 Mart'ta iktidarın değiştiği ülkede, Rusya Devlet Duması'nda bulunan "ilerici Blok", "Geçici Devlet Duması Komitesini" ihdas ederek iktidara geçti. Daha sonra liberal düşüncenin savunucu Prens Lvov'un başkanlığında geçici bir koalisyon hükümeti kuruldu $^{13}$. Böylece 15 Mart'ta Lvov, 12 kişilik ekibiyle Geçici Hükümetin başına geçti. Her ne kadar hükümetin başkanı Lvov olmuşsa da asıl yetki Adalet Bakanı ve Başbakan Yardımcısı sosyalist Kerenski'deydi ${ }^{14}$.

Rusya'daki Şubat ihtilali, bir asırdan beri Rus tahakkümü altında olan İran'da büyük bir heyecan yarattı. 15 Mart 1917'de Imparator Çar Nikola'nın tahtan feragat ettiğine ve geçici bir hükümetin kurulduğuna dair bir belge, Rusya Dışişleri Bakanı Melikof tarafından Tahrandaki Rus temsilcisine iletildi. Ayrıca bu belgede yeni rejimin dış politikasının şekillendiği ve Dışişleri Bakanlığının, Geçici Hükümetin politikalarını uygulamakla yükümlü olduğu ve dış politika ilkelerinden en önemlisinin müttefik devletlerle ilişkilerin geliştirilmesi olduğu vurgulandı. Devamında, Rusya'da yeni rejim ile kurulan ilişkilerin daha iyi olacağı ve ulusların demokratik prensiplerine saygı gösterileceği belirtilmekteydi. Bu belge, İran'a ulaştıktan sonra İranlılar büyük bir sevinç yaşadılar. Çünkü Çarlığın devrilmesi, uzun yıllar işgal altında kalan İranlılar için özgürlük anlamına gelmekteydi ${ }^{15}$. Geçici Hükümetin iyimser telgrafına karşıık 20 Mart 1917'de İran Başbakanı Vüsuk'üd-Devle (d. 1868 - ö. 1950) Melikof'a cevap vererek Rusya'daki gelişmelerden memnun

\footnotetext{
${ }^{11}$ Serpil Sürmeli, Türk-Gürcü Iliş̧kileri (1918-1921), Ankara 2001, s. 1.

12 Abdülazim Rezai, Tarihe Deh Hezar Sale Iran,. Tehran 1378, s. 205.

${ }^{13}$ Oral Sander, Siyasi Tarih (ilkçağlardan 1918'e), Ankara 2008, s. 390.

${ }^{14}$ Cevad Şeyh'ü-I Selami, Simaye Ahmed Şah Kaçar, C. 1, Tehran, 1367, s. 97.

${ }^{15}$ Neyyire Delir, "Berresi Tebyiki Monesabate Seyasi Dovlete Enkelabe Fevriye u Enkelabe Okteber Rusya Ba Dovlete İran", Biannual of Journal Historical Studies of Islamic World at Imam Khomeini Specialized University, C. 3/5, (2015), s. 11.
}

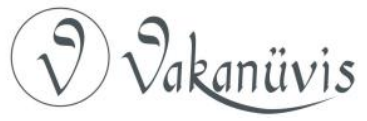


olduklarını bildirdi. 2 Nisan 1917 tarihinde ise İranlı bir grup siyasetçi ve eski meclis üyesi 71 kişi Tahran'dan Petrograt'daki Duma Meclisine bir kutlama telgrafı gönderdiler ${ }^{16}$. Telgrafta; eski parlamento milletvekillerinin, Rus ulusunun zafere ulaşmak için verdikleri mücadeleden dolayı oldukça mutlu oldukları ifade edilmekteydi. Devamında ise Rusya'daki gelişmelerin övülmeye değer olduğu ve "Doğu ile Batı arasında böylesine güçlü ellerin yaktığı meşalenin karanlık evrenin ışığını tamamladığını ve dolayısıyla aynı prensipler çerçevesinde hareket eden milletlerin birbirlerini anlayacak ve birbirlerine kardeşçe sevgi eli verebilecekler ${ }^{\prime 17}$ denilmekteydi.

Tahran ile Petrograt arasındaki yazışmalar bu şekilde karşılıklı olarak devam etti. Son olarak 30 Nisan 1917'de Rus Duması, Tahran'daki eski meclis üyelerine cevap yazdı: Eski meclis milletvekillerine diye başlayan telgrafta, parlamento üyelerinin Rusya'daki özgürlüğün zaferi vesilesiyle ifade ettikleri tebrik ve dileklerinden Duma'nın derinden etkilendiğini ve Duma adına içten minnettarlık ve mutluluk duyulduğu ifade edilmekteydi. Ayrıca iki devlet arasındaki ilişkilerin kaba kuvvetten ziyade samimi kardeşlik bağlarıyla birleştirilerek, dünyada barış̧ıl bir ortamın gecikmeyeceği vurgulanmaktayd $\iota^{18}$.

İran'daki siyasi otoritenin yanı sıra halk da ihtilali gerçekleştirenlerin gerçek niyetlerinden habersiz olduğu için bu intilali kendi istibdat rejimlerinden bir kurtuluş olarak görmekteydi ${ }^{19}$. Ihtilalin verdiği cesaretle henüz Rus işgali altında olan Tahran, Rest, Tebriz ve İran'ın diğer şehirlerinde işgal karşıtı ileri gelenler tarafından birçok toplantı yapıldı. Bu toplantılarda öne çıkan en önemli mesele, îhtilal sonrası takip edilecek siyasetti. Dolayısıyla toplantılarda İran'daki istibdattın sona ermesi ve demokratik bir cumhuriyet idaresinin kurulması üzerinde duruldu. Fakat bu toplantılar genellikle İran'da bulunan Rus uyruklu şahıslar tarafından yönlendirilmekte ve teşvik edilmekteydi. Hatta bu toplantıların bir kısmı, bu şahısların talepleri doğrultusunda Tahran'daki

\footnotetext{
${ }^{16}$ Mohammad Gholi Majd, Persia in World War I and Its Conquest By Great Britain, University Press of America, New York 1984, s. 142.

${ }^{17}$ Delir, a.g.m., s. 11.

${ }^{18}$ Majd, a.g.e., s. 142.

${ }^{19}$ Yılmaz Karadeniz, Kaçar Hanedanı 1795-1925), İnönü Üniversitesi Sosyal Bilimler Enstitüsü Basılmamış Doktora Tezi, Malatya 2004, s. 342.
}

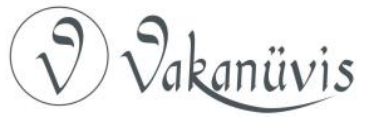


Rus Başkonsolosunun odalarında yapılmaktaydı ${ }^{20}$. Aynı şekilde İran basını da Rusya'daki ihtilalin İran'daki Rus tahakkümünü sona erdireceği fikrindeydi. Nitekim Tebriz'de yayımlanan demokratların yayın organı "Teceddüd Gazetesi" 31 Mayıs 1917 tarihinde "iran ve Özgür Rusya" başıklı yazıda:

"Yüce Rus Milletinin en parlak dönemini oluşturan bu devrim, özgür Rusya ve Iran halkı arasında iyi komşuluk ilişkilerini sağlamlaştırmak için çok güzel bir fırsat yaratmıştır. Illeri görüşlü Rus halkının yaptığı bu büyük devrim, onları dünya hürriyetçilerinin odak noktası yapmıştır. Onlar buraya gelinceye kadar, yıllarca gaddar ve zalim Rus hükümetlerinin baskısı altında acı çektiler. Sömürgeci Rus Hükümetlerinin Iran ve Iran halklarına karşı izlediği politika sadece Iran halkı değil, Rus halkının da onlardan nefret etmesine sebep olmuştu. Iran halkı, Rus milletinin hiçbir zaman kendi mutluluğunu başka bir milletin mutsuzluğu pahasına elde etmek istemeyeceklerini iyi bilir. Özellikle tarihi komşuları olan iranlıların ilerlemesini içtenlikle istedikleri herkes tarafından bilinmektedir. Ne yazık ki, eski Rus hükümetinin Iran ve Iran halklarına karşı uyguladığı sömürgeci politikası, derin bir nefret duygusunun yaratılmasına neden olmuştu. Onların izlediği politika sonucu Iran halkı, arzuladığı hedeflere ulaşamadı, milli serveti uzun yıllar sömürgeci devletler tarafından yağmalandı. Her zaman felaketlerden sonra ümit ve mutluluk geliyor. Iran halkları yıllar yılı mahrumiyet ve baskı altında yaşadıktan sonra Rusya'nın iyi niyetli, ileri görüşlü yüce milletine sevgi ve dostluk duyguları beslemektedir. Iran halkı bağımsızık ve gelişme için Rus milletinden anlayış ve yardım beklemektedir" ${ }^{\prime 21}$ demekteydi.

Rusya ile İran arasındaki samimi yazışmalar ve İran halkının umutları bir süre sonra Rus Geçici Hükümetinin gerçek niyetini ortaya koymasıyla yerini karamsarlığa bıraktı. Nitekim Iranlılar, topraklarının Rus işgalinden kurtulacağı düşüncesinde olmalarına rağmen Geçici Hükümet, aslında intilali dış politikadan etkilenmemesi gereken bir tür iç mesele olarak değerlendirmekteydi. Daha önce de İngiliz Dışişleri Bakanının, 23 Mart 1917 tarihinde Rus ihtilali ile ilgili Avam Kamarasında verdiği beyanatta, intilalin barışı sağlamak için değil aksine savaşa daha büyük bir şiddetle devam etmek amacıyla tertip edildiğini ileri sürmüştü ${ }^{22}$. İngiliz Dışişleri Bakanının bu beyanatı çok geçmeden Rusya Dışişleri Bakanı tarafından

\footnotetext{
${ }^{20}$ Majd, a.g.e., s. 144.

${ }^{21}$ Ali Azeri, Azadistan Devleti ve Şeyh Muhammed Hıyabani 1918-1920, Elila Elektronik Illetişim Ajansı, Ankara 1995, s. 61-62.

${ }^{22}$ Sevilya Aslanova, 20. Yüzyıl Başında Rusya'nın Osmanlı Politikası, Ankara 2011, s. 236.
}

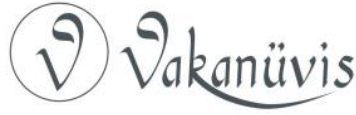


da doğrulandı. Nitekim 18 Nisan 1917'de Rusya Dışişleri Bakanı Melikof, savaştaki Rus müttefiklerine bir muhtırada şunları söylemekteydi: "Bütün Rus milleti, nihai zafere ulaşana kadar savaşı sürdürmek istiyor." Dolayısıyla Geçici Hükümetin savaş sırasındaki politikası, ihtilal ve ordu içindeki kayıplara rağmen savaşta Rusya'nın varlığını devam ettirmesiydi. Bu durum Mayıs'ta Rus ordusunun tekrar kuvvetlenmesi intimalini doğurdu. Ruslar, savaşa devam etmeye karar verdikten sonra amaçlarının diğer uluslara boyun eğdirmek ya da topraklarını ele geçirmek değil, fakat daha önce Çar tarafından imzalanan tüm antlaşmalar geçerli olacaktı. Nitekim Melikof, Tahran'daki Rusya büyükelçiliğine gönderdiği bir telgrafta; "Şah hükümetine, Rusya'nın Iran meselelerinde Ingiltere ile işbirliği yapacağını ve Rusya'nın politikasında hiçbir değişiklik olmayacağını bildirmeliyiz" diyordu. Aynı şekilde İran ile yapılan antlaşmaların da geçerli olacağı bildirildi. Geçici Hükümetin bu düşüncesi, İran halkının beklentilerinin aksine İngiltere ve Fransa'nın çıkarlarına uygundu. Çünkü Geçici Hükümet, müttefikleri İngiltere ve Fransa'nın beklentilerini daha fazla önemsemekteydi. Bu durum İranlı özgürlükçülerin umudunu yok ederken genel olarak İran'da yeni Rus hükümetinin politikasının, çarların politikasından pek farklı olmadı̆̆ı düşüncesine sebep oldu ${ }^{23}$.

Rusya'daki Geçici Hükümet, savaşa devam etme kararı aldıktan sonra bazı cephelerde Rus ordusunun tekrar güçlenmesini sağlasa da Bolşeviklerin baskısı altındaydı. Çünkü Bolşevikler, Geçici Hükümetin aksine savaş taraftarı değillerdi. Bunun üzerine 6-7 Kasım 1917 gecesi Lenin ve Trocki önderliğindeki Bolşevik Partisi, bir darbe ile Geçici Hükümeti devirerek iktidarı ele geçirdiler ${ }^{24}$. Bolşeviklerin, Geçici Hükümet'ten farkı, "ilhak veya tazminatların" olmadığı, "demokratik" bir barış sağlamak için savaşı sona erdirmekti. Petrograd'daki Bolşeviklerin çoğu da aynı çizgideydi ${ }^{25}$. Nitekim Bolşeviklerin Petersburg'da iktidarı ele geçirmelerinin ertesi günü, 8 Kasım 1917 (eski takvimle 26 Ekim'de) de yayımlanan barış bildirgesi tüm savaşan devletlere, "hemen savaşa son vermeleri, bırakışma imzalamaları, hiçbir toprak parçası ilhak etmeksizin ve savaş tazminatı ödemeksizin, tam anlamıyla demokratik, adil bir

\footnotetext{
23 Delir, a.g.m., s. 11-13.

24 Yusuf Hikmet Bayur, Türk Inkılâbı Tarihi (1914-1918). C. 3/4, Türk Tarih Kurumu Yayınları, 1991, s. 92.

${ }^{25}$ Car, a.g.e., s. 14.
}

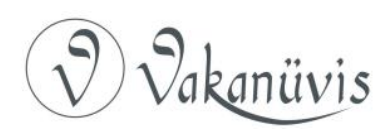


barışa varmaları" çağrısında bulundular. Bolşeviklerin bu çağrısına İtilaf devletlerinin tepkisi, kendi cephe durumlarını değerlendirmelerine ve ihtilalin kendi iç işlerine yansıyacağı endişelerine sebep oldu ${ }^{26}$.

Rusya Dışişleri Komiseri Troçki de 21 Kasım 1917'de Itilaf devletlerinin elçilerine verdiği notalarda "ilhaksız ve tazminatsız" bütün cephelerde mütareke yapılmasını istedi ${ }^{27}$. Bolşeviklerin politikası, kendi kaderini tayin hakkı ve demokratik özgürlük dilini kullanarak sadece kendi tahakkümleri altında ezilen halkların değil, işgal atındaki bütün halkları kapsamaktaydı. Çünkü siyasi durumları ne olursa olsun hepsi de emperyalist devletlerin müdahalesine ve tahakkümüne maruz kalmışlardı. Bu durumda İran da zaten yarı sömürge bir devletti ve Sovyet politikası, Çar'ın eski tebaalarına ve sözde bağımsız olan ve aslında aslen bağımlı olan halklara seslenmekteydi. Nitekim, 24 Kasım/ 7 Aralık 1917'de Sovyetler, "Rusya'daki ve Doğu'daki bütün Müslüman Emekçilere " hitaben bir bildiri yayımladılar ${ }^{28}$. Bildiride, Rusya Müslümanlarına İnanç ve örflerinin, ulusal ve kültürel kurumlarının bundan böyle daha özgür ve koruma altında olacağı teminatı veriliyordu. Doğulu Müslümanlar arasında İranlılar, Türkler, Araplar ve Hindular özellikle zikredilirken bu ülkeleri, "soyguncularını ve köle tacirlerini" devirmeye teşvik ediyordu. Ayrıca İran'ın bölünmesine sebep olan 1907 Antlaşması'nın iptal edilecek ve askeri harekâtlar biter bitmez birlikler İran'dan çekilecekti ${ }^{29}$.

Bolşeviklerin çağrıları bilhassa işgal altında tuttukları topraklarda büyük yankı uyandırdı. Özellikle "Her millet kendi kaderini tayin etme özgürlügüne kavuşmuştur" şeklindeki açıklama İranlıları da heyecanlandırdı. Bu durum İranlıların iyiden iyiye bağımsızlıktan söz etmelerine sebep oldu ve İranlı diplomatlar, Bolşeviklerle iletişime geçtiler. Bunun üzerine Moskova'daki İran büyükelçiliğinin üçüncü

\footnotetext{
${ }^{26}$ Selami Kılıç, "Türk-Alman Kaynakları Işığında Sovyet İhtilali Sonrası Kafkasya”. Birinci Dünya Savaşında Karadeniz ve Kafkasya, Askeri, Siyasi ve Sosyal Gelişmeler, Karadeniz Teknik Üniversitesi Yayınları, Trabzon 2017, s. 174.

${ }^{27}$ Fahir Armaoğlu, 20. Yüzyıl Siyasi Tarihi, Timaş Yayınları, İstanbul 2013, s. 132; Mustafa Çolak, Enver Paşa, Osmanlı-Alman Ittifakı, Yeditepe Yayınevi, İstanbul 2008, s. 140.

${ }^{28}$ Bildirinin tamamı için bknz: Şeyh'ü-I Selami, a.g.e. s. 98.

29 Şeyh'ü-I-Selami, a.g.e., s. 98; Ebbas Brumende Elem u Azer Melek Ehmedof, "Monesebatte Hokomete Şurevi Ba Moselmanane Sakine Rusye der Deh Evvele Enkelabe Bolşeviki (1917-1927)", Moteleate Tarihe Islam, C. 10/38, (1397), s. 72-73.
}

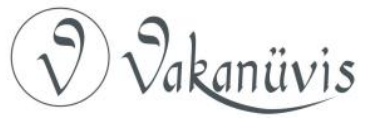


sekreteri Hassan Farzaneh, Bolşevik hükümetinin dışişleri komiseri Troçki ile bir araya geldi. Farzaneh'in amacı, uzun zamandır Rus işgali altında bulunan İran topraklarının ve bu süre zarfında Rusların İran'daki yıkıc faaliyetlerine dikkat çekmekti. Nitekim Ferzaneh, İran'da çarların eylemleri ve trajedilerinin ayrıntılı bir tanımını yaptı ve Troçki'yi etkileyip İran lehinde düşünmesi için çabaladı. Bu görüşmenin ardından, 16 (5) Aralık 1917'de Sovyetler Birliği Ulusal Komiserleri Başkanı Lenin tarafından yeni açıklamalar yapıldı. Açıklamada; dış baskılarla ezilen Müslüman ulusları, fırsatı değerlendirmelerini ve işgalci güçleri ülkelerinden kovmanın zamanı geldiğini söylemekteydi. Bunun için de Rusya Müslümanları ile Doğulu Müslümanların bu yolda kendilerine yardımlarına intiyaçları olduğunu vurgulamaktaydı. Lenin'in bu açıklamaları İranlıları oldukça heyecanlandırmaktaydı. Çünkü İran'ı kendi aralarında bölen Rusya ve İngiltere'nin önceki antlaşmalarının iptal edileceğini ve savaş biter bitmez Rusların İran'ı tahliye edip kendi kaderlerini belirlemeyi kendilerine bırakacağını da vaat etmekteydi ${ }^{30}$. Lenin'in İran hakkındaki düşünce ve vaatleri bir mektupla daha sonra Tahran'da görevlendirilen Sovyet diplomatı Karl Bravin aracılığıyla 18 Ocak 1918'de İran yönetimine iletildi. Mektupta, Çarlık Rusya'sının İran hakkındaki niyetleri tek tek sıralanmakta ve eleştirilmekteydi ${ }^{31}$.

íktidarı ele geçiren Bolşeviklerin ilk işi, gizli antlaşmaları dünya kamuoyuna açıklamak ve İttifak devletleriyle barış antlaşmalarını başlatmak oldu. Bolşevikler, müttefiklerine de barış çağrısında bulunmuş fakat onlardan olumlu bir cevap alamadılar. Bunun üzerine İttifak Devletleri ile barış görüşmelerine yalnız devam ettiler ${ }^{32}$. Bolşevikler, İttifak devletlerinin de barış antlaşmasına sıcak bakmasıyla Brest-Litovsk'ta görüşmeler 22 Aralık 1917'de başladı ${ }^{33}$. Sovyet Rusya temsilcileri İttifak devletleri temsilcilerine genel olarak, "toprak kaybına uğramadan, tazminat ödemeden ve milletlerin geleceklerini kendilerinin belirlemeleri" ilkesine göre, bir barışın yapılmasını önerdiler. 26 Aralık 1917 'de Bolşeviklerin bu istekleri kabul edildi. Aynı gün Alman ve Rus temsilcileri arasında yapılan görüşmelerde Almanlar, Osmanlı topraklarının (Doğu Anadolu) boşaltılmasını istemiş, kendilerinin de

\footnotetext{
30 Neyyiri, a.g.m., s. 13.

${ }^{31}$ Majd, a.g.e., s. 146.

32 Bayur, a.g.e., s. 118-119.

${ }^{33}$ Armaoğlu, a.g.e., s. 125.
}

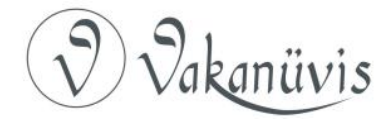


Rusya'ya kalacak olan yerleri aynı zamanda boşaltacaklarını söylediler. Bu görüşmeler 29 Aralık’a kadar devam etti. Görüşmelerin sonunda Almanlar işgal etmiş oldukları toprakları boşaltmayı ve o bölgede referandum yapılmasını kabul ettiler. Sadece referandumun toprakları boşaltmadan önce mi yoksa sonra mı yapılmasına karar verilemedi. Ruslar ile İttifak Devletleri arasında yapılan ilk görüşmeye 31 Aralık 1917'de son verildi ${ }^{34}$.

Barış görüşmeleri devam ederken İran'ın da bazı beklentileri vardı. Nitekim İran'ın Berlin Sefiri Hüseyin Kuli, Rus yetkililerin ümit verici açıklamalarından da cesaret alarak ülkesinin bağımsızlığı ve toprak bütünlüğünün sağlanması hususunda bazı şartlar öne sürmüştü. Bu şartlar arasında; Türkmençay Antlaşması (10 Şubat 1828) maddelerinin gözden geçirilmesi ve İran'ın Hazar Denizi'nde bir donanmaya sahip olmasını engelleyen kapitülasyonların iptal edilmesi ${ }^{35}$, Rusların İran' da el koyma haklarının kaldırılması, İran hükümetine gümrük tarifelerini serbestçe oluşturma özgürlüğünün verilmesi, 1907 Rus-İngiliz Anlaşması'nın iptali, Rusya ve İngiltere'ye her türlü taviz verme hakkının gözden geçirilmesi, İran'ın yurtdışında kredi sözleşmesi yapma özgürlüğünün sağlanması, 1911 Rus ültimatomuyla yabancı ülkelerden getirilen danışman ve memurlar için izin alınması şartının kaldırılması ${ }^{36}$,

\footnotetext{
${ }^{34}$ Akdes Nimet Kurat, "Brest-Litovsk Müzakereleri ve Barış (20 Aralık 1917-3 Mart 1918)", Belleten, C. XXXI/123, (1967), s. 377.

35 Türkmençay Antlaşması'na göre Hazar Denizi'nde her iki devletin de ticaret gemileri yüzebilecek, fakat yalnızca Rusya'nın savaş gemileri bulunabilecekti. Yeşilot, a.g.m., s. 189-190.

${ }^{36} 1907$ Rus-İngiliz Antlaşması'ndan geri adım atmak istemeyen Ruslar, yeni hükümetin antlaşmayı tanımadığını açıklaması üzerine, 1911 Kasım ayında İran hükümetine bir nota verdi. Rusya'nın notasında; hükümetin anlaşmayı uygulamaması durumunda, İran'ın Rusya-Ingiltere ortak işgaline uğrayacağı açıkça belirtiliyordu. Notada ayrıca, meclisin kapatılması ve Rusya ve İngiltere karşıtı kişilerin kabineden atılmasının yanı sıra Amerikalı Shuster'in ülkeden kovulması da isteniyordu. Ali Reza Mulai, "Baz Hovani Movzu Seyasi Moderres der Beraber Oltimatum 1911 Rusya be İran", Jostarha-yi Seyasi Moesser, Pojoşgah-i Ulum-i Ensani u Moteleat Ferhengi, C. 1/6, (1394), s. 96; Erwand Abrahamian, "The Crowd in the Persian Revolution". Iranian Studies, S. 2/4, (1969), s. 188; Paine and Schoenberger, a.g.e., s. 7. Bunun dışında yabancı memur çalıştırmak için Rusya ve Ingiltere'den izin alınacaktı. Azeri, a.g.e., s. 8. 24 Aralık 1911'de İran Parlamentosu, Rus ve İngiliz baskısı sonucu Meclisi lağvetme ve Şhuster'i görevden almak zorunda kaldı. Mulai, a.g.m., s. 97; Mohammad Reza Djalili ve Thierry Kellner,
}

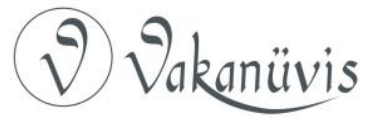


İran'ın askeri bir güce sahip olma ve onu istenen kapsamda genişletme özgürlüğü, İran'ın kendi topraklarında Rus uyruklu göçmenlerin yerleşmesini engelleme özgürlüğü, diplomatik temsilcilere ve Rus vatandaşlarına, İran'da kira, mülk veya kırsal bölgelerde sahip oldukları bölgeleri yönetme hakkının iptali, İran silahlı kuvvetlerinin ve maliyesinin Rusya ve İngiltere'nin idaresi ve kontrolü altına alınmasını talep eden bir notanın iptali, İran'da silahlı müfreze bulundurma hakkının veya elçilikleri için konsolosluk muhafızları unvanının, başka herhangi bir kurumdaki çeşitli konsolosluklarının iptali37. İran'ın içişlerine ve özellikle valilerin ve çalışanların atanmasında Rus müdahalesinin sona ermesiydi ${ }^{38}$.

İran'ın Berlin sefiri bu şartları öne sürerken Brest-Litovsk'taki görüşmeler sırasında görüşülen önemli konulardan biri de İran meselesiydi ve Hüseyin Kuli'nin daha önce öne sürdüğü şartların neredeyse tamamı bu görüşmeler sırasında ele alınmaktaydı. İran ile ilgili en önemli mesele "tarafsız Iran Devleti'nin özgürlüğü, bağımsızlığı ve toprak bütünlüğü ilkesi" ile hem Rus hem de Türk birliklerinin İran'ı tahliye etmeleriydi. Bu ilke çerçevesinde bazı konular gündeme geldi: İran'ı üç nüfuz bölgesine ayıran 1907 tarihli Rus-íngiliz Antlaşması'nın iptali, İran'a, maliye askeriye ve jandarma teşkilatlarında yabancı memurlar istihdamı konusunda tam bir serbestlik verilmesi ve Rus müdahalesinin sona ermesi, Rusya'nın daha önce İran'a vermiş olduğu notaların iptali edilmesi, İran topraklarında yaşayan Rus tebaalarının İran kanunlarına göre yargılanmaları ${ }^{39}$, savaşta İran harp ve ticaret

Iran'ın Son Iki Yüzyılıık Tarihi, çev. Reşat Uzmen, Bilge Kültür Sanat Yayınları, İstanbul 2011, s. 48.

371907 Rus-İngiliz Antlaşması ile İran'ın istihdam edeceği asker miktarı memleketin ihtiyacına göre düzenlenmiş ve dolayışla İran'ın kuvvetli bir orduya sahip olması engellenmişti. Sonraki dönemde ise 5 Ağustos 1916 tarihli notayla Şah'ın malumatına dahi gerek duyulmadan Rus zabıtanların İran jandarma teşkilatında görev almaları ve maliyede memur bulundurmaları karara bağlanmıştı. (Türkiye Cumhuriyeti Cumhurbaşkanlığı Devlet Arşivleri Başkanlığı Osmanlı Arşivi, Hariciye Nezareti, Siyasî Kısım, 2340/69. Bundan sonraki kullanımlarda bu arşiv tasnifi (BOA. HR. SYS.) olarak kısaltılmıştır.

${ }^{38}$ BOA. HR.SYS., 2340/84.

39 Daha önce Rus tebaaları İran yasalarına göre yargılansalar da cezalarının tatbiki Rus konsoloslarının imtiyazına bırakılmıştı. Bu durumda gerek hukuk ve gerekse cezai muhakemede Rus konsolosu hak ve hukukta malik bulunuyordu. BOA. HR. SYS., $2340 / 69$.

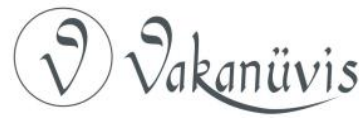


gemilerinin seyrü sefirlerinin ve gümrük tarifelerinin yeniden tatbiki ve ıslahının temin edilmesi ${ }^{40}$, İran'ın mali durumuna darbe vuran İran ve Rus devletleri veya Rus tebaasıyla İran devleti ile aralarında akdedilen antlaşmaların ılgasaydı (BOA. HR. SYS. 2340/69).

Brest-Litovsk'ta İran'ın lehine önemli kararlar alınırken, Troçki de 14/27 Ocak 1918 tarihinde İran halkına yönelik bir bildiri yayımladı. Bildiride, Rusya ile İngiltere ya da başka devletler arasında İran'la ilgili olarak yapılmış anlaşmaları açıkça tanımadığını ilan ediyordu. İran'a yönelik alınan bu önemli kararlar, müttefiki İngilizleri kaygılandırmaktaydı. Çünkü Bolşeviklerin İran'dan çekilmek istemeleri ve daha önce İngilizlere İran'ı bölen antlaşmalarını iptal edeceklerini duyurmaları İran'da İngilizleri zor durumda bırakabilirdi. Nitekim İngilizler, İran'da Rusların çekilecekleri bölgelerdeki boşluğu doldurmak amacıyla harekete geçtiler. Tahran'da yayımlanan Bamdad Ruşen Gazetesi'nin 3 Aralık 1917 tarihli haberinde İngilizlerin İran Meclisine seçilecek milletvekillerinin kendi taraftarları olması için İngiliz taraftarı bakanlar vasıtasıyla Ahmet Şah nezdinde teşebbüslerde bulunmaktaydılar. Fakat Ahmet Şah, bu duruma tepkiliydi. Çünkü Şah, şimdiye kadar İran aleyhinde faaliyette bulunan İngilizlerin şimdi de mebuslar vasıtasıyla İran'ın içişlerine karışmasına engel olmak istiyordu. Bunun dışında İngilizler, İran'daki polis ve askeri teşkilatı ele geçirerek bu kurumlarda söz sahibi olmak istiyorlardı. Sadece İran Şah'ı değil Rus İhtilali'nin verdiği cesaret sebebiyle İran gazeteleri de Ruslar ve İngilizler aleyhinde haberler yapmaya başlamışlardı. Halk da Rus ve İngilizler aleyhine dönmüştü. İngiliz ve Rus taraftarı olan şahısların ise cezalandırıldığı söylenmekteydi. İngilizlerin İran'daki faaliyetleri bir kesim arasında etkili olmuştu. Nitekim Demokratların bir kısmı İngiliz taraftarı bir siyaset izlemekteydiler ${ }^{41}$.

Brest-Litovsk'taki görüşmeler henüz devam ederken Viyana'da çıkmakta olan Abendblatt Gazetesi'nde 1 Şubat 1918 tarihinde Troçki tarafından bir nota yayımlandı. Troçki notasında 1907 yılında İngiltere ve Rusya arasında akdedilen ve İran'ı üç bölgeye ayıran antlaşma hakkında

\footnotetext{
${ }^{40}$ Türkmençay Antlaşması ile İran'ın Hazar Denizi'nde harp ve ticaret gemisi bulundurmasının yasaklanmasının yanış sıra gümrük tarifelerinin uygulanmasında İran'ın menfaati göz ardı edilmişti. BOA. HR. SYS., 2340/63.
}

${ }^{41} B O A$. HR. SYS., 2340/63.

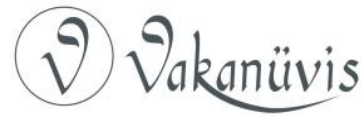


bilgi vermekteydi. Troçki, İran halkının tereddütlerine sebep olan ve İran halkının hürriyet ve istiklalini tehdit ve ihlal eden antlaşmanın lağvedileceğini ve henüz İran topraklarından çekilmeyen Rus askerleri yüzünden İran halkının düçar olduğu ve askerlerinde çekileceğinden bahsetmekteydi ${ }^{42}$. Troçki, aynı kararını bir mektupla daha sonra İran'ın Petrograd'daki Büyükelçiliğine bildirdi ${ }^{43}$. Mektupta, İngiliz-Rus anlaşmasının İran'ın bağımsızlığını ihlal ettiği için feshedildiğini ve aynı şekilde bundan önceki tahakküm edici anlaşmaların da kaldırıldığını bildirmekteydi ${ }^{44}$. Bu arada barış görüşmeleri, 10 Şubat'ta Troçki'nin İttifak devletlerinin Ukrayna ile antlaşma imzalamalar ${ }^{45}$ üzerine aniden kesildi. Ukrayna ile yapılan barışı şiddetle protesto eden Troçki, "Sovyet Rusya'nın savaştan çekildiğini, ordularını tamamen terhis edeceğini, fakat toprak ilhakına dayanan böyle bir barış anlaşmasını imzalamayı reddettiklerini" ${ }^{\prime \prime 6}$ açıkladı.

Barış görüşmelerinin kesilmesi üzerine Almanlar cephelerde Ruslara karşı tekrar harekete geçtiler. Bunun üzerine zor durumda kalan Rusya, barış anlaşmasının imzalanmasını kabul etti ve nihayet Brest-Litovsk Antlaşması; Rusya, Türkiye, Almanya, Avusturya-Macaristan ve Bulgaristan arasında 3 Mart 1918'de imzalandı ${ }^{47}$. Brest-Litovsk Antlaşması ile Rusya, görüşmeler sırasında söz verdiği gibi İran'dan tamamen çekilecekti. Tarafsız İran Devleti'nin hürriyet, istiklâl ve toprak bütünlüğü göz önünde bulundurularak, Osmanlı ve Rus başkumandanlıkları ordularını İran'dan çekeceklerdii" Ayrıca İran'da daha önce çarlık tarafından inşa edilen şose, banklar, mektepler ve savaş sırasında inşa edilen Culfa-Tebriz demir yolu ile daha önce aldıkları diğer imtiyazları İran'a devrettiler. Rus askerlerinin İran'dan çekilmesinin

\footnotetext{
${ }^{42}$ Şeyh'ül- Selami, a.g.e., s. 102.

${ }^{43} B O A$. HR. SYS., 2340/94.

${ }^{44}$ Seriyye Genceliyeva, "Ekim Devrimi'nin İran'a Etkileri”, 100. Yılında Sovyet ihtilali ve Türk Dünyası, Hacettepe Üniversitesi Türkiyat Araştırmaları Enstitüsü Yayınları, Ankara 2018, s. 911.

${ }^{45}$ Rusya, Ukrayna'nın İttifak devletleriyle ayrı barış yapmasını istemiyordu. Buna rağmen 9 Şubat 1918'de İttifak devletleriyle Ukrayna Halk Cumhuriyeti arasında I. Dünya Savaşı'nın ilk barışı imzalanmıştı. Kılıç, a.g.m., s. 176.

${ }^{46}$ Kılıç, a.g.m., s. 176.

47 Türkiye Cumhuriyeti Cumhurbaşkanlığı Devlet Arşivleri Başkanlığı Osmanlı Arşivi, Hariciye Nezareti İstişare Odası (HMŞ. İ̧O.), 68/42.

48 Kurat, "Brest-Litovsk Müzakereleri", s. 378.
}

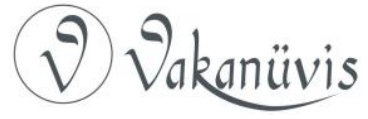


kararlaştırılması üzerine de daha önce Rus zabitleri tarafından teşkil ve idare edilen İran Kazak kuvvetlerine ait askeri mallar İran'a verildi. Rusların bütün bu şartları kabul etmesinin altında yatan önemli sebeplerden biri İran halkını kendi lehlerine çevirmekti. Ayrıca İngilizlerin bölgedeki faaliyetlerine bu şekilde set çekmekti ${ }^{49}$. Rusların İran'dan çekilmeleri, bölgede Rusya ile fiili mücadele halinde olan Osmanlı ve Almanya devletleri için avantajlı bir durum ortaya çıkardı. Özelikle Osmanlı Devleti'nin doğu sınırları için önemli bir tehlike ortadan kalkmış oldu. Öteden beri Rus ve İngiliz tahakkümü altındaki İslâm coğrafyalarında yürütülmeye çalışılan İttihat-ı İslâm politikasına bağlı olarak İran üzerindeki Türk nüfuzunun artmasını sağladı ${ }^{50}$.

Brest-Litowsk Antlaşması ile İran'ın tahliyesine dair alınan karar Şah'ı memnun etti. Osmanlı Padişah'ı tarafından 4 Mart 1918 tarihinde İstanbul'daki İran sefirine bir kutlama telgrafı gönderildi. Telgrafta akdedilen sulh sebebiyle Şah hazretlerine İran'ın istiklal ve hürriyetine kavuşmasından duyulan memnuniyet ve sevinç paylaşılmaktaydı ${ }^{51}$. Şah da karşılık olarak, "Osmanlı Devleti'nin izhar eylediği hissiyat-ı dostaneden duyduğu memnuniyeti" 52 Osmanlı Dışişlerine bildirdi. Fakat Osmanlı Devleti'nin İran'ın bağımsızlığına ve toprak bütünlüğüne dair söz konusu antlaşmada ortaya koyduğu tavır, İran kamuoyunda takdirle karşılanmasına ve iki ülke arasında iyi ilişkiler gelişmesine rağmen İran hükümetinin İran'ın kuzeyine dair çekinceleri devam etti Çünkü İran hükümeti, Osmanlı Ordusu'nun tekrar İran'ın kuzeyine gireceğinden korkuyordu Bu konuda savaşın başından itibaren Rus ve İngilizler 'in yaptığı propagandaya ilave olarak, yukarıda da ifade edildiği gibi, Alman faaliyetleri de Kuzey İran konusunda İran'ın hassasiyetini arttırmıştı. ${ }^{53} \mathrm{Bu}$ duruma Tahran ataşemiliteri Ömer Fevzi Bey de Harbiye Nezaretine gönderdiği 12 Mart 1918 tarihli telgrafında açıkça dikkat çekmektedir.

\footnotetext{
49 Doktor Fahreddin Şevket, Irran, haz. Derya Örs, Türk Tarih Kurumu Yayınları, Ankara 2017, s. 96.

50 Barış Metin, Birinci Dünya Savaşı'nda Iran Coğrafyasında Etnik, Dini ve Siyasi Nüfuz Mücadeleleri, Gazi üniversitesi Sosyal Bilimler Enstitüsü Yayımlanmamış Doktora Tezi, Ankara 2007, s. 162.

${ }^{51}$ BOA. HR. SYS., 2296/2.

52 Türkiye Cumhuriyeti Cumhurbaşkanlığı Devlet Arşivleri Başkanlığı Osmanlı Arşivi, BabI Ali Evrak Odası (BOA. BEO)., 4528/339597.

${ }^{53}$ Karabalık, a.g.t., s. 120.
}

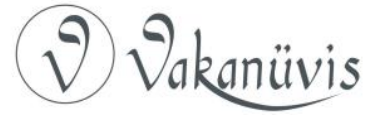


Ömer Fevzi Bey'in bildirdiğine göre; İran'ın kuzeyine bir Osmanlı fırkasının girdiği hakkındaki çıkan bir şayia İranlılar arasında heyecana neden olmuştu. İran'ın en hassas noktasının Kuzey İran olduğunu belirten Ömer Fevzi, İranlıların bu konuda hassas olduklarını belirtiyordu. Hatta İran'ın kuzeyine Osmanlı birliklerinin girmesi değil, İran'ın kuzeyi sözünün geçmesinden bile endişelenmekteydiler. Dolayısıyla Ömer Fevzi, böylesi bir hassa konuda İran'a yapılacak her teşebbüste kendi görüşünün alınmasını veya bilgilendirilmesini istemiş ve bu gibi teşebbüslerin bir yanlış anlamaya neden olmaması için vaktiyle münasip bir şekilde İranlıların haberdar edilmesinin ve muvafakatlerinin alınmasının uygun olacağını bildirmekteydi ${ }^{54}$.

\section{Rus Askerlerinin İran'ı Tahliyesi}

Ihtilal patlak vermeden önce Rusya'nın cephelerdeki durumu henüz savaşın ikinci yılından itibaren bozulmaya başlamıştı. Bunun altında yatan sebep de yine Rusya'nın iktisadi vaziyetinin kötüleşmesiyle ilgiliydi. Nitekim ülkedeki fabrikaların çoğu kapanmış, kara borsacılık artmış ve nihayetinde ortaya çıkan hayat pahalılığı halkın günlük ihtiyacını karşılayamayacak duruma gelmesine sebep olmuştu. Buna rağmen savaş zenginleri lüks içinde yaşamakta, servet sahibi kimseler de çocuklarını askerlik muafiyetinden tutmak amacıyla iltimas ya da varlıklı kimselere rüşvet vermekteydiler. Bütün bunlar halkın gözünden kaçmadığı gibi Rus ordusu içerisinde de hoşnutsuzlukların artmasına sebep olmaktaydı ${ }^{55}$. Yine 1917 'de kış şartlarını zorluğu, sağlık hizmetlerin yetersizliği, harekât sahasında bulaşıcı hastalıkların kol gezmesi buna karşılık askerlere yeterli derecede aşı tatbik edilmemesi, doktor ve hastane yetersizliği, yiyecek ve giyecek eksikliği de kayıpların artmasına sebep oldu ${ }^{56}$. Ayrıca savaş bıkkınlığı askerlerin cephelerden firar etmesine sebep oluyordu. Nitekim Rusların savaştıkları cephelerde 1917 yılına doğru kaçak asker sayısı bir buçuk milyona dayanmıştı ${ }^{57}$. Bu durum İran'da bulunan Rus askerleri arasında da yaygındı.

\footnotetext{
54 Metin, a.g.t., s. 164-165.

55 Akdes Nimet Kurat, Rusya Tarihi, Başlangıçtan 1917'ye Kadar, Türk Tarih Kurumu Basımevi, Ankara 1987, s. 424.

${ }^{56}$ Fahri Belen, Birinci Cihan Harbinde Türk Harbi, 1917 Yılı Hareketleri, C. 4, Ankara: Genelkurmay Basımevi, Ankara 1964, s. 194-195.

57 Kurat, Rusya Tarihi, s. 424.
}

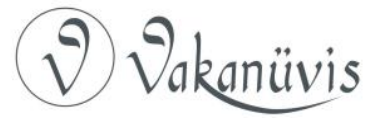


İhtilal başladığında İran'da özellikle de Kuzey İran'da çok sayıda Rus askeri üssü bulunuyordu. Bunlar çarlık adına Osmanlı Devleti ile savaşan Ermeni-Nasturi birliklerini örgütleyen ve İran'daki halka karşı her türlü şiddet olayına karışmış güçlerdi ${ }^{58}$. Rusya'daki iktisadi kriz halkın tepkisi sonucunda gösterilerin başlamasına sebep olduğunda İran'da bulunan bu güçler, yeni planlar yapmaktaydılar. Bu plan, Irak'ta (Kutu'I-Amare) Osmanlı ordusu karşısında hezimet yaşayan Ingilizlere yardım ulaştırmaktı. Rus Kafkas Ordusu'nun planı, Sivas ve Sinop hattına kadar olan İç ve Doğu Anadolu topraklarını işgal ettikten sonra Güneye doğru harekete devam ederek Musul yoluyla Irak'taki İngiliz birlikleri ile birleşmekti ${ }^{59}$. Ingilizler, Bağdat'ı Türklere karşı korumak amacıyla Rusların Musul'a doğru ilerlemelerini kabul etmişti. Bu plan, İngilizlerin Kilikya sahiline çıkarma yapmaları sureti ile Türk ordularının imhası maksadı ile sağlanacaktı ${ }^{60}$. Şubat ìntilali'nin patlak vermesiyle bu plan sonuçsuz kaldı ve harp bıkkını askerler arasında ihtilal sevinçle karşılandı. Fakat Geçici Hükümet beklenilenin aksine askerleri İran'dan çekmedi ve savaşmaya devam etme karar aldı. Bunun üzerine İran'a 70.000 civarında yeni asker gönderildi ${ }^{61}$.

Geçici Hükümetin aksine Bolşevikler, iktidarı el geçirdikten sonra savaş karşıtı bir politika izlediklerinden Rusların savaştıkları diğer cephelerde olduğu gibi bu durum İran'da da etkisini gösterdi. Savaşın ilk iki yılında zaten muharebe etme isteğini kaybeden İran'daki Rus askerleri içinde ihtilal, hızlı bir şekilde yankı buldu. Buradaki Rus askerleri, Bolşeviklerin İttifak devletleri ile barış görüşmelerini sürdürdüğü sırada beyaz bayrak açarak "yakında sulh olacak" diye bağırmaya başladılar. Sulh imzalanacağını düşünen askerler, müzik çalarak, havalı fişek ve bomba atarak sevinçlerini gösteriyorlardı. Bazı Rus askerleri de bulundukları cephelerin bazı kısımlarına kırmızı bayrak asarken, bazıları da ellerinde kırmızı bayrakla dolaşıyorlardı. Osmanlı

\footnotetext{
58 Belen, a.g.e., s. 194.

59 Mustafa Çolak, Alman Imparatorluğu'nun Doğu Siyaseti Çerçevesinde Kafkasya Politikası (1914-1918), Türk Tarih Kurumu Yayınları, Ankara 2006, s. 176.

60 Belen, a.g.e., s. 193.

${ }^{61}$ Kaveh Farookh, Iran at War (1500-1988), Osprey Publising, Oxford 2011 s. 237.
}

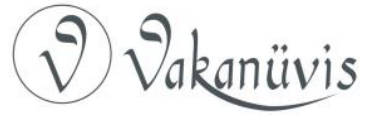


askerlerinin icra edilen ateşlerine karşı da onlara beyaz bayrak göstererek karşılık vermekteydiler ${ }^{62}$.

Rus askerlerin çoğunluğunun beyaz bayrak açmaları artık savaşmak istemediklerinin bir göstergesiydi. Bu durum askerlerin disiplinden çıkmasına sebep oldu. 28 Nisan'da II. Kafkas Türk Kolordusunun karşısında 153. Rus Alayı erleri, ellerinde "yaşasın cumhuriyet" yazııı bayraklar ile konuşma isteğinde bulunduktan sonra siperlerine geri dönüyorlardı ${ }^{63}$. Bilhassa Kuzey İran'da on binlerce askerin olduğu bölgelerde ciddi dipsizlikler baş gösterdi. 1916 yılına kadar bölgede görevli iyi bir birlik olan Rus Kazak birliği içindeki erler de görev yerlerini terk etmeye başladılar ve üstlerine itaat etmeyi bıraktılar. Bazı önemli Rus uyruklu şahıslar da askerler tarafından tutuklandılar ${ }^{64}$. Birliklerinden bağımsız hareket etmeye başlayan bu erler, şarap ya da başka alkollü içecekler tedarik ederek bölgede sarhoş bir şekilde gezmeye başladılar ${ }^{65}$. Düzeni ve birliği bozulan bu Rus askerleri iaşelerini temin edemediklerinden çevreyi yağmalamaya başladılar ${ }^{66}$. İran'ın diğer vilayetlerinde bulunan Rus askerleri arasında da durum pek farklı değildi. İsfahan'da bulunan Kazak askerleri görevlerini ifa etmekten vazgeçmişler ve üstlerine selam vermeyi de bırakmışlardı. Bazı askerler ise eşkıyalığa başlamışlardı. Bu askerlerin bir kısmı da şarap ve rakı tedarik ederek içip sızıyorlardı. Devriye ve emniyet hizmetlerine de son verilmişti. İsfahan ve çevresi bu eşkıya çetelerinin kontrolü altına geçmişti ${ }^{67}$. Askerler artık savaşmayı reddettiklerinden silahlarını bırakarak memleketlerine dönmek istiyorlardı. İran hükümetinin otorite kuracak jandarma ve polis gücünden yoksun olması sebebiyle bu kargaşa ortamı gittikçe genişledi. Fakat çevresine iyi davranan askerler de vardı. Savaşmak istemeyen Tebriz'deki Rus askerleri halka "arkadaş" veya "yoldaş" şeklinde hitap etmekteydiler ${ }^{68}$.

\footnotetext{
62 BOA. HR. SYS., 2113/13.

63 Belen a.g.e., s. 194-195.

${ }^{64}$ Majd, a.g.e., s. 143.

65 Percy Sykes, A History of Persia, C. 2, London 1921, s. 486.

66 M. Larcher, Büyük Harpte Türk Harbi, çev. Mehmet Nihat, C. 2, İstanbul 1927, s. 425.

67 Sykes, a.g.e., s. 487.

68 Karabalık, a.g.t., s. 114; Touraj Atabaki, "I. Dünya Savaşı, Büyük Devletler Arasındaki Çekişmeler ve İran' da Siyasal Toplumun Doğuşu”. Iran ve Birinci Dünya Savaşı, Ed. Touraj Atabaki, Çev. Gül Çağalı Güven, Tarih Vakfı Yurt Yayınları, İstanbul 2007, s. 3-4.
}

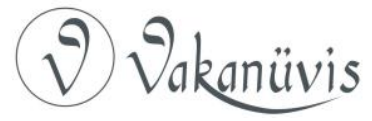


İran hükümetinin içinde bulunduğu vaziyetten dolayı Rusların çekilmekte oldukları bölgeler büyük zarar görmekteydi. Rusya iç savaşa girerken, Bolşevikler, İran'da kalan tüm Rus subaylarının Rusya'ya dönmesini talep etmişlerdi ${ }^{69}$. Ancak General Baratov ve Bicherakov kumandanlığındaki Rus birliklerinin bir kısmı ve İran Kazak Tugayı subayları Sovyet Komutanlığına itaat etmeyi ve geri dönmeyi reddettiler. Bunlar 800 asker ile 114 subaydan ibaretti. Rusya'nın ihtilalci yönetimine tabi olmak istemeyen bu asker ve subaylar, bölgede kalarak Ermeni ve Nasturilerden oluşan 20 bin kişilik bir orduyu eğitmeye başladılar ${ }^{70}$ ve İngilizlerin askerlik hizmetlerine katıldılar. Bunlar dışında Rus yetkililerin çağrılarına uymayan diğer tüm çarlık diplomatları, Sovyet Rusya'nın diplomatik hizmetinden men edildiler ${ }^{71}$.

Rus İhtilali, İran'da birkaç istisna dışında, askerlerin cephelerinden düzensiz bir şekilde geri çekilmelerine yol açmıştı ${ }^{72}$. Bu birlikler Hazar sahillerine doğru çekilmeye başlayıp, silahlarını bıraktılar veya satıp, vatanlarına erken dönmekteydiler. Bu askerler çekilirken Urmiye kasabasında iki yüz dükkânı yağmaladılar. Aynı şekilde Tebriz'deki Pazar da bu askerlerden dolayı oldukça zarar gördü ${ }^{73}$. Bu sırada bölgede bulunan Osmanlı birlikleri ise Salmas'ı zapt edip ileri hareketlerine devam etmekteydiler. Salmas'taki Ermeni ve Nasturiler de Ruslar birlikte geri çekilirken çevredeki Müslüman köylerine tecavüz ediyorlardı. Bu arada Müslüman köylerine tecavüz edenler Osmanlı askerleri tarafından yakalanıp cezalandırılıyorlardı. Rusların geri çekilmesi ile cephenin uzun vadesinde güneydeki Hanikin'den kuzeydeki Kafkasya'ya kadar ciddi bir boşluk açıld $\imath^{74}$.

\footnotetext{
${ }^{69}$ Farookh, a.g.e., s. 237.

70 Talas Avşarlı, "Birinci Dünya Savaşı'nda Güney Azerbaycan'da Asuri, Ermeni ve Kürt İsyanı”. Güney Azerbaycan Sosyal Kültürel ve Siyasal araştırmaları Dosyası, S. 4, (2005), s. 79.

${ }^{71}$ M. Mamedova, "Russia ii. Iranian-Soviet Relations (1917-1991)," Encyclopædia Iranica, https://iranicaonline.org/articles/russia-ii-iranian-soviet-relations-1917-1991 (Erişim tarihi:20.01.2021).

72 Türkiye Cumhuriyeti Cumhurbaşkanlığı Devlet Arşivleri Başkanlığı Osmanlı Arşivi, Dâhiliye Nezareti, Emniyet-i Umumiye, 2. Şube, (BOA. DH. EUM. 2. ŞB): 84/6. Bundan sonraki kullanımlarda bu arşiv tasnifi (BOA. DH. EUM. ŞB.) olarak kısaltılmıştır.

${ }^{73}$ Ahmed Kesrevi, Tarih-i Hicdeh Sale-i Azerbaycan, İntişarat-ı Emir Kebir, Tehran 1350, s. 706.

${ }^{74}$ BOA. DH. EUM. 2. ŞB. 3/66.
}

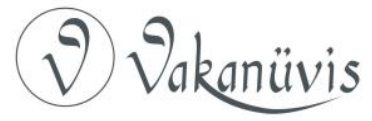


Rusların bölgeden çekilmesi, Hazar boyunca Orta Asya'da OsmanlıAlman gücünün oluşmasını belirgin hale getirdi. İngilizler, bu Türk-Alman gücü karşısında kaygılanmaya başladılar ${ }^{75}$. Ayrıca Rusların askerlerini İran'dan çekmeye karar vermeleri üzerine İngilizler, bölgede yalnız kaldılar. Bu boşluğu doldurmak isteyen İngilizler, bölgede siyaset değişikliğine gittiler. Rus askerlerinin İran'dan çekilmesini önlemek amacıyla Rusların daha önce askerlerine ödedikleri aylık 100 bin tümeni kendileri vermeye teşebbüs ettiler. Bir diğer teşebbüsleri de Kazvin yakınlarında bulunan merkez ordugâhlarını Bağdat-Kazvin-Reşt arasına nakletmek oldu. İngilizlerin buradaki amaçları hem yeni Rus yönetiminin aleyhine çalışmak ve hem de İran'ın kuzey batısındaki Osmanlı ilerleyişini önlemekti. Bir diğer önlemde General Dunsterville komutasındaki orduyu Bağdat-Hemedan-Reşt üzerinden Bakü'ye göndermekti. Fakat İngilizlerin bu planı o sırada Gilan'ı elinde bulunduran ve yabancılara karşı isyan etmiş olan Mirza Küçük Han'ın direnişi ile karşılaştı ${ }^{76}$.

Brest-Litovsk Antlaşması sonucu Osmanlı birliklerinin de İran'ı terk etmesi gerekiyordu. Fakat İngiliz, Ermeni ve Nasturilerin Ruslardan boşalan yerlere yerleşmeleri bunu olanaksız hale getirdi. Savaş boyunca tarafsızı̆̆ını ilan eden İran Hükümeti de bu meselenin çözülmesini istiyordu. İran'ın tarafsızlığına saygı duyulmasını isteyen İran hükümeti, Osmanlı Devleti'nin İran topraklarını boşaltmadığını üstelik bölgedeki aşiretleri tahrik edip İran topraklarına yeni birlikler gönderdiklerinden şikâyet ediyordu. Üstelik İran topraklarının tahliyesinin Rus ve İngilizlerden de talep edildiğini Osmanlı askerlerinin de aynı şekilde İran'ın tarafsızlığına saygı duyup boşaltmasını istemekteydi ${ }^{77 .}$ İran hükümetinin bu taleplerine Osmanlı Devleti, İran'ın istiklal ve tarafsızlığına riayet edilmesi gerektiğinden tahliye için gerekli emrin verildiğini bildirdi ${ }^{78}$.

Rusların bölgeden ayrılması sonucu ortaya çıkan otorite boşluğu yeni sorunları ortaya çıkardı. İran'ın şehir, kasaba ve köylerinde otorite

\footnotetext{
75 George Lenczowskı, "Foreign Powers" Invension in Iran During Word War I", Qajar Iran (1800-1925), Ed: Edmund Bosworth and Carole Hillenbrand, Edinburgh University Press, Edinburgh 1983, s. 87.

76 Karadeniz, Kaçar Hanedanı, s. 342.

77 BOA. HR. SYS. 2340/43.

${ }^{78}$ BOA. HR. SYS. 2340/50.
}

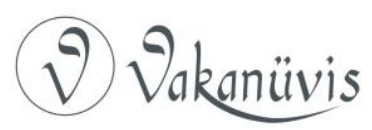


boşluğunun ortaya çıkması ve İran hükümetinin güçlü bir ordu gücünden yoksun olması büyük bir kargaşa ortamının oluşmasına sebep oldu. Ruslar, bölgeden çekildikten sonra kendilerinden geriye kalan cephaneden en çok faydalanan Ermeni ve Nasturiler oldu. Ermeni ve Nasturileri eğitmek üzere Tiflis'ten çok sayıda İngiliz ve Fransız subay İran'a geldi ${ }^{79}$. Bu sırada İran'daki Ermeni ve Nasturilere savaş sırasında aileleriyle beraber Osmanlı topraklarından göç eden 12.000 Celov (Osmanlı Nasturileri) katılmıştı. Ayrıca Erivan, Nahcivan ve Van'dan gelen Ermeni sayısı da 5000'den fazla idi. Salmas, Urmiye ve Salduz şehirlerindeki bu kuvvetlerin toplamı 20.000 kişi olmuştu. Bu birliklere 800 Rus ve 72 Fransız komutan önderlik ediyordu. Fransız ve Ruslar dışında Amerikan Konsolosları ile Urmiye'de yaşayan Amerikan Hıristiyan Misyonu ve Fransız hastanesi müdürünün de yardımıyla ${ }^{80}$ İran'da bilhassa Urmiye ve Salmas havalisinde toplanan Ermeni ve Nasturiler ihdas ettikleri askeri teşkilatlar sayesinde bölgede üstünlük kurmuşlard ${ }^{81}$. Birinci Dünya Savaşı'nın başlaması ile birlikte kendilerine bir "Ermenistan Devleti" kurma karşılı̆̆ında Rusların yanında savaşan ve Anadolu'dan göç eden Ermenilerce de takviye edilen bölge Ermenileri, Rus askerlerinden geriye kalan silah, cephane ve iaşe ambarlarını ele geçirerek Osmanlı Devleti'nin daha önce Ruslar tarafından işgal edilmiş olan topraklarında bir Ermenistan vücuda getirmek istiyorlardı. Bunlar yavaş yavaş büyüyerek, taburlar, alaylar teşkil etmeye başladılar ${ }^{82}$.

Nasturilerin de Ermenilere benzer arzuları vardı: Urmiye ve Salmas havalisinde bağımsız bir devlet kurma hayali olan Nasturiler, Bolşevik intilali sonrasında Osmanlı kuvvetlerinin Tebriz'e yapacağı olası bir askerî harekât karşısında İngilizlerin güdümünde tampon vazifesi göreceklerdi. Nasturiler de Ermeniler gibi Ruslardan geriye kalan silah ve diğer askeri teçhizatları ele geçirdiler ve bazı gönüllü Rus subaylarınca

\footnotetext{
79 Avşarlı, a.g.m., s. 80.

80 Yılmaz Güneyli, "I. Dünya Savaşı'nda Güney Azerbaycan'da Osmanlı-Rus Rekabeti”, Güney Azerbaycan Sosyal, Kültürel ve Siyasal Araştırmaları Dosyası, Güney Azerbaycan Tanıtım Cemiyeti, (2005), s. 31-32.

${ }^{81}$ E. Aysan, Büyük Harpte Iran Cephesi, C. 3, İstanbul Askerî Matbaası, İstanbul 1938, s. 1.

82 Martin Van Bruinessen, "20. Yüzyılın Başında Türk-İran Sınırında Bir Kürt Mütegallibe", Iran ve Birinci Dünya Savaşı, Ed. Touraj Atabaki, Çev. Gül Çağalı Güven, Tarih Vakfı Yurt Yayınları, İstanbul 2010, s. 90.
}

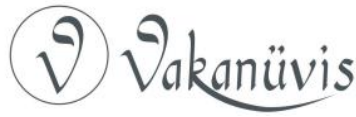


desteklenmeye devam edildiler. İngilizler de Bakü petrollerinin Alman ve Osmanlı tehlikesi altında olduğunu düşündüklerinden Nasturileri desteklemeye başladılar. Bu amaçla 1917 yılının Aralık ayında Ingiliz subay Yüzbaşı Gracey Van'dan Urmiye'ye geçti. Burada Nasturileri örgütleyerek, Osmanlı birliklerine karşı savaştırmak için gizli toplantılar tertip etti. İngiliz subay dışında bu toplantıya Amerikalı misyon müdürü Mr. Shedd, Rusya konsolos vekili Mr. Nikitin, Urmiye'deki Fransız Piskoposu Monsignor ve Nasturi Patriği gibi Nasturi temsilcileri de katıldı. Toplantı da genel olarak Nasturilerin savaşması üzerinde duruldu ve karşılık olarak kendilerine askeri ve mali destek verileceğini ayrıca Nasturilerin hayalini kurdukları bağımsızlık isteklerinin düşünüleceği sözü verildi. Bunun üzerine harekete geçen Nasturiler, bölgedeki Müslümanlara zarar vermeye başladılar. Bunun dışında bir Fransız misyonu da Nasturilere kendilerini Türklere karşı korumaları için silah dağıtıyordu. Bu arada İngilizler Urmiye'deki Nasturilerle irtibat kurma ve Nasturi başıbozuklarını Tebriz'e yönelik bir Türk akınına karşı savaş gücüne dönüştürme girişiminde bulundu ${ }^{83}$. Bu sırada 29 Mart 334 (29 Mart 1918) tarihinde alınan bir telgrafa göre Savuçbulak ve Salduz'a gelen Ermeni ve Nasturilerin de içerisinde bulunduğu 400 Rus Kazak askeri Savuçbulak ve Salduz arasındaki karayı tahrip ettikten sonra ele geçirdikleri erzakla Savuçbulk'a geri çekilmişlerdi. Ruslar Salmas ve civarına yerleştirdikleri Van Ermenileri ile Nasturiler yardımıyla Kafkasya'daki ordularının iaşelerini temin için erzak gasp etmeye gasp ediyorlardı. Ruslar, Ermeni ve Nasturiler aracılığıyla buradan topladıkları zahireyi gemilerle gönderdikten sonra Savuçbulak'tan Tebriz'e geçmişlerdi ${ }^{84}$.

Ermenilerin ve Nasturilerin bölgedeki yıkıcı faaliyetlerinden yerel Müslüman halk (Kürtler ve Azeriler) memnun değildi. Dahası İran hükümeti de rahatsızdı. Rusların bölgeden ayrılması ile başlayan karşılıklı intikam arayışları Hıristiyanlarla Müslümanlar arasında acımasız bir şiddetin artmasına sebep oldu. Hıristiyanlar daha iyi silahlanmış olduklarından en fazla zararı Azerbaycan Türkleri ile herhangi bir aşirete mensubiyeti olmayan Kürtler gördü. 1918 yılında Urmiye'de Kürtler ile Ermeniler ve Nasturiler arasında başlayan çatışmalarda Nasturiler galip

${ }^{83}$ Karabalık, a.g.t., s. 113; Bruinessen, a.g.m., s. 72-73.

${ }^{84}$ BOA. DH. EUM. 2. ŞB., 15/9.

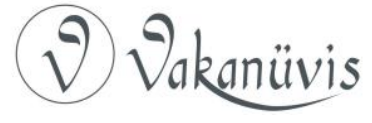


geldi ve kente hâkim oldular ${ }^{85}$. Bu olaylar sırasında Ermenilere Ağa Petros, Nasturilere, Marşimon kumandanlık etmekteydi. Ihtilal sonrası ülkelerine dönmeyi reddeden bazı Rus askerleri de 1918 yılında Ermenilere destek vererek Hoy, Salmas ve Urmiye'de Türklere ve Kürtlere büyük kıyımlar yaptılar. Günümüzde Urmiye trajedisi olarak kayıtlara geçen bu olaylar sırasında Müslüman erkeklerin çoğu katledilmiş, kadınların ise ya ırzına geçilmiş ya da tutsak edilmişlerdir. Bu olayların yaşandığı bir gece 1500 Azerbaycanlı öldürüldü ${ }^{86}$.

İran hükümeti, İran'ın kuzeyinde meydana gelen karışıklıklardan Osmanlı Ordusunun ilerleyişinin sebep olduğunu iddia ediyordu. Bu iddiaya karşııı Osmanlı Devleti, gerekli tahkikatı yaptıktan sonra İran hükümetine olayların sebebi hakkında cevap verdi. Yapılan tahkikata göre Ermenilerin Osmanlı askerleri tarafından katledildiğinin aslının olmadığı, Tebriz ve Meraga dolaylarında yaşayan Ermenilerin huzur içinde yaşadıkları ve yalnızca Hoy, Dilman ve Urmiye civarında meskûn olan Ermenilerin, Nasturiler ile birlikte bir hükümet teşkiline niyetlenmeleri üzerine üzerlerine usulen hareket edildiği bildirildi ${ }^{87}$.

\section{Sonuç}

Rusya'nın bir asırdan fazla süren İran üzerindeki tahakkümü nihayet Bolşevik İtilali ile sona erdi. Ruslar, XIX. yüzyıldan itibaren İran karşısında elde ettikleri bütün ayrıcalıklarından vazgeçtiler. Bu durum İran'da özgürlük yanlısı grupların ilk defa demokrasiden söz etmelerine sebep oldu. Cumhuriyet ve Demokrasi fikirlerinin tartışılmasının yolunu açtı.

Savaş öncesinde Rusya'nın İran'a askeri yığınak yapması ve Ermeniler, Nasturiler ve bazı Kürt aşiretleri arasındaki faaliyetleri bölgeyi etnik çatışmaların alanı haline getirdi. Ermeniler, Nasturiler ve Kürtlere verilen devlet kurma vaatleri, onları Rusya ve müttefikleri yanında savaşa sürüklese de ilk hayal kırıklıklarını Rusya'nın Bolşevik ihtilali ile savaştan çekilmeleri sonucu yaşadılar. Çünkü İhtilal sonucu ellerinde hiçbir şey kalmadı ve üstelik bölgede zor durumda kaldılar. Bundan

\footnotetext{
85 Bruinessen, a.g.m., s. 90.

${ }^{86}$ Anar İskenderli, Realities of Azerbaijan (1917-1920), Xlibris Corporation, 2001 s. $132-$ 133.

${ }^{87}$ Karabalık, a.g.t., s. 117.
}

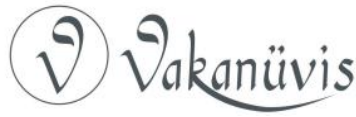


dolayı bölgede etnik çatışmalar daha da arttı ve binlerce insan bu çatışmalarda hayatını kaybetti. Nasturiler, bu çatışmalardan kurtulmak için yerlerini terk ederek Musul'a göç etmek zorunda kaldılar. Aynı şekilde bölgede tutunamayan bazı Kürt aşiretleri de Osmanlı topraklarına göç ettiler. Bu da beraberinde yeni sınır sorunlarını gündeme getirdi. Bu durum Osmanlı Devleti ile İran arasında uzun süre çözülemeyen sorunlara sebep oldu.

Bolşevik ihtilali ile Ruslar bölgeden çekildikten sonra bölgede bu sefer İngiliz, Ermeni ve Nasturi tehlikesi daha da arttı. Bolşevik intilali ile her ne kadar Rus ordusu bölgeyi terk etse de tahliye sırasında geçtikleri bölgeleri yağmaladılar ve evleri ateşe verdiler. Ayrıca Rusların yağma faaliyetlerine karşı duran Kürt aşiretlerinin Rus askerilerine saldırması küçük çatışmaların yaşanmasına sebep oldu. Rusların çekilmesi ile kendilerinden geriye kalan teçhizatları ele geçiren Ermeni ve Nasturiler bölgede büyük katliamlar yaptılar. İngiltere ise bölgedeki boşluğu hem Hindistan'ı tehlikeye sokacağı gerekçesiyle hem de Bakü petrollerini Osmanlı ve Almanlara kaptırmamak için bölgeye asker sevk etti. Bu da bölgedeki karmaşanın daha da artmasına sebep oldu. Bu sırada İran'dan Kafkasya'ya göç eden fabrikalarda ve petrol sahalarında çalışan işçiler, Bolşevik ihtilalinden sonra eve döndüklerinde işsizler ordusuna katıldılar

Bolşevik îhtilali sonucu Rus askerlerinin bölgeden çekilmesi İran hükümetinin içinde bulunduğu durumu değiştirmedi. İran nüfusu arttığı gibi fakirleşti, ekonomi çöktü, neredeyse iflas etti. İran hükümeti, Ermeni, Nasturi ve Kürtler gibi yerel güçler tarafından kuşatıldı. Bölgesel protesto hareketleri mevcut duruma meydan okumaya başladı. Hükümetin, bütün önlemleri yetersiz kaldı. Bölgede tek otorite olarak asker kaçakları ile birlikte milliyetçi motivasyonlu kişilerden oluşan ve yüzlerce Osmanlı askeriyle de tahkim edilen Simko İsmail Ağa kaldı. Dolayısıyla bölge uzun bir süre daha kaos içerisinde kaldı.

\section{Kaynakça}

Türkiye Cumhuriyeti Cumhurbaşkanlığı Devlet Arşivleri Başkanlığı Osmanlı Arşivi (BOA) ${ }^{88}$

Hariciye Nezareti Siyasi Kısım Belgeleri (HR. SYS.)

${ }^{88}$ Arşiv belgelerinin numaraları metin içerisinde verilmiştir.

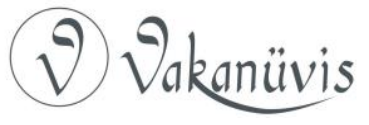


BOA, Bab-ı Ali Evrak Odası (BEO)

BOA, Dâhiliye Nezareti Şifre Kalemi (DH. ŞFR)

BOA, Dâhiliye Nezareti, Emniyet-i Umumiye, íkinci Şube Belgeleri

BOA. Hariciye Nezareti İstişare Odası (HMŞ. İ̧O.)

\section{Kaynak Eserler, Araştırma ve Incelemeler}

Armaoğlu, Fahir, 20. Yüzyıl Siyasi Tarihi, Timaş Yayınları, İstanbul 2013.

Aslanova, Sevilya, 20. Yüzyıl Başında Rusya'nın Osmanlı Politikası, Ankara 2011.

Atabaki, Touraj, "I. Dünya Savaşı, Büyük Devletler Arasındaki Çekişmeler ve İran'da Siyasal Toplumun Doğuşu". Iran ve Birinci Dünya Savaşı, Ed. Touraj Atabaki, Çev: Gül Çağalı Güven, Tarih Vakfı Yurt Yayınları, İstanbul 2007, ss. 1-9.

Avşarlı, Talas, "Birinci Dünya Savaşı'nda Güney Azerbaycan'da Asuri, Ermeni ve Kürt İsyanı", Güney Azerbaycan Sosyal Kültürel ve Siyasal araştırmaları Dosyası, S. 4 (2005), ss. 75-83.

Aysan, E, Büyük Harpte Iran Cephesi, C. 3, İstanbul Askerî Matbaası, İstanbul 1938

Azeri, Ali, Azadistan Devleti ve Şeyh Muhammed Hıyabani 1918-1920, Elila Elektronik Iletişim Ajansı, Ankara 1995.

Bayur, Yusuf Hikmet Türk Inkılâbı Tarihi (1914-1918), C. 3/4, Türk Tarih Kurumu, Ankara 1991.

Belen, Fahri, Birinci Cihan Harbinde Türk Harbi, 1917 Yılı Hareketleri, C. 4, Genelkurmay Basımevi, Ankara 1964.

Bruinessen, Martin Van, "20. Yüzyılın Başında Türk-İran Sınırında Bir Kürt Mütegallibe". Iran ve Birinci Dünya Savaşı, Ed. Touraj Atabaki, Çev: Gül Çağalı Güven, Tarih Vakfı Yurt Yayınları, İstanbul 2010.

Car, E. H, Sovyet Rusya Tarihi, Bolşevik Devrimi (1917-1923), Çev: Tuncay Birkan, Metis Yayınları, İstanbul 2004.

Cezani, Bijan, Iran Meşrutiyet Devrimi (1906-1911), Kaynak Yayınları, İstanbul 2004.

Çolak, Mustafa, Alman imparatorluğu'nun Doğu Siyaseti Çerçevesinde Kafkasya Politikası (1914-1918), Türk Tarih Kurumu Yayınları, Ankara 2006.

Çolak, Mustafa, Enver Paşa, Osmanlı-Alman Ittifakı, Yeditepe Yayınevi, İstanbul 2008.

Delir, Neyyire, "Berresi Tebyiki Monesabate Seyasi Dovlete Enkelabe Fevriye u Enkelabe Okteber Rusya Ba Dovlete İran", Biannual of Journal Historical Studies of Islamic World at Imam Khomeini Specialized University, C. 3/5, (2015), pp. 7-36.

Elem, Ebbas Brumende u Ehmedof, Azer Melek, "Monesebatte Hokomete Şurevi Ba Moselmanane Sakine Rusye der Deh Evvele Enkelabe Bolşeviki (19171927)", Moteleate Tarihe islam, C. 10/38, (1397).

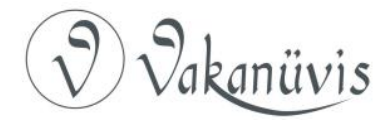


Erwand, Abrahamian, "The Crowd in the Persian Revolution". Iranian Studies, S. 2/4, (1969), pp. 128-150.

Farrokh, Kaveh, Iran at War (1500-1988), Osprey Publising, Oxford 2011.

Genceliyeva, Seriyye, "Ekim Devrimi'nin İran'a Etkileri”, 100. Yılında Sovyet ihtilali ve Türk Dünyası, Hacettepe Üniversitesi Türkiyat Araştırmaları Enstitüsü Yayınları, Ankara (2018), ss. 911-919.

Güneyli, Yılmaz, “I. Dünya Savaşı'nda Güney Azerbaycan'da Osmanlı-Rus Rekabeti", Güney Azerbaycan Sosyal, Kültürel ve Siyasal Araştırmaları Dosyası, Güney Azerbaycan Tanıtım Cemiyeti, Ankara 2005, ss. 21-39.

Issawi, Charles, "Iranian Trade, 1800-1914". Iranian Studies, S. 16, (1983), pp. 229-241.

İskenderli, Anar, Realities of Azerbaijan (1917-1920), Xlibris Corporation, 2001.

Karabalık, Kamuran, Birinci Dünya Savaşı'nda Güney Azerbaycan, Bolu Abant İzzet Baysal Üniversitesi, Sosyal Bilimler Enstitüsü Yayımlanmamış Doktora Tezi, Bolu 2019.

Karadeniz, Yılmaz, Iran'da Sömürgecilik Mücadelesi ve Kaçar Hanedanı (1795-1925), Bakış Yayınları, İstanbul 2006.

Karadeniz, Yılmaz, Kaçar Hanedanı 1795-1925), Inönü Üniversitesi Sosyal Bilimler Enstitüsü Basılmamış Doktora Tezi, Malatya 2004.

Kesrevi, Ahmed, Tarih-i Hicdeh Sale-i Azerbaycan, Intişarat-ı Emir Kebir, Tehran 1350.

Kılıç, Selami, "Türk-Alman Kaynakları Işığında Sovyet ihtilali Sonrası Kafkasya", Birinci Dünya Savaşında Karadeniz ve Kafkasya, Askeri, Siyasi ve Sosyal Gelişmeler, Karadeniz Teknik Üniversitesi Yayınları, Trabzon 2017, ss. 173-229.

Kurat, Akdes Nimet, "Brest-Litovsk Müzakereleri ve Barış (20 Aralık 1917-3 Mart 1918)", Belleten, C. XXXI/123, (1967), ss. 375-413;

Kurat, Akdes Nimet, Rusya Tarihi, Başlangıçtan 1917'ye Kadar, Türk Tarih Kurumu Basımevi, Ankara 1987.

Larcher, M., Büyük Harpte Türk Harbi, C. 2, Çev. Mehmet Nihat, İstanbul 1927.

Lenczowskı, George, "Foreign Powers" Invension in Iran During Word War I", Qajar Iran (1800-1925), Ed. Edmund Bosworth and Carole Hillenbrand, Edinburgh University Press, Edinburgh 1983, pp. 76-93.

Majd, Mohammad Gholi. Persia in World War I and Its Conquest By Great Britain, University Press of America: New York, 1984.

Mamedova, M., "Russia ii. Iranian-Soviet Relations (19171991)," Encyclopædia Iranica, https://iranicaonline.org/articles/russia-iiiranian-soviet-relations-1917-1991 (Erişim tarihi:20.01.2021).

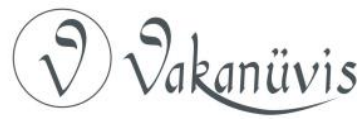


Metin, Barış, Birinci Dünya Savaşı'nda Iran Coğrafyasında Etnik, Dini ve Siyasi Nüfuz Mücadeleleri, Gazi üniversitesi Sosyal Bilimler Enstitüsü Yayımlanmamış Doktora Tezi, Ankara 2007.

Mulai, Ali Reza, "Baz Hovani movzu Seyasi Moderres der Beraber Oltimatum 1911 Rusya be İran", Jostarha-yi Seyasi Moesser, Pojoşgah-i Ulum-i Ensani u Moteleat Ferhengi, 1/6, (1394), ss. 115-95.

Neyyiri, Lokman Dehkan, "Yüzyılın İlk Yarısında İran ve Osmanlı Devletlerinin Zayıflatılması ve Avrupa'nın Bundaki Rolü", Onuncu ve Yirminci Yüzyıllar Arasında Iranlılar ve Türklerin Batıyla Ilişskileri, Çev. Sayyid Abu Talib Ruhani, Ziya Türkyılmaz, Omid Rambod, Uluslararası Kültürel İncelmeler Merkezi, Tahran 2005.

Niyâ, Cafer Mehdi, Heft Bar İşgal-i Iran der 23 Karn, C. 4, İntişarat-ı Panos, Tehran 1377.

Paine, Chris; Schoenberger, Erica, "Iranian Nationalism and the Great Powers: 1872-1954". MERIP Reports, S. 37 (1975), pp. 3-28,

Rezai, Abdülazim, Tarihe Deh Hezar Sale Iran, Tehran 1378.

Sadıgov, Ramin, "Bolşeviklerin Geçici Hükümeti Devirme Girişimi: 1917 Temmuz Ayaklanması”, Tarih incelemeleri Dergisi, C. XXXIV / 1, (2019), ss. 229268.

Sander, Oral, Siyasi Tarih (illkçağlardan 1918'e), Ankara 2008.

Sürmeli, Serpil, Türk-Gürcü iliş̧kileri (1918-1921), Ankara 2001.

Sykes, Percy, A History of Persia, C. 2, London 1921.

Şevket, Doktor Fahreddin, Iran, haz: Derya Örs, Türk Tarih Kurumu Yayınları, Ankara 2017.

Şeyh'ü-I Selami, Cevad, Simaye Ahmed Şah Kaçar, C. 1, Tahran 1367.

Ünal, Fatih, "Şikak Aşireti ve Reisi Simko Lakaplı İsmail Ağa'nın Faaliyetleri", Tarih Dergisi, C. 0/44, (2006), ss. 169-198.

Yeşilot, Okan, "Türkmençay Antlaşması ve Sonuçları", A.Ü. Türkiyat Araştırmaları Enstitüsü Dergisi, S. 36, (2008), ss. 187-199. 